\title{
SISTEM PEMILU PROPORSIONAL DAFTAR TERBUKA DI INDONESIA: MELAHIRKAN KORUPSI POLITIK?
}

\author{
Diah Ayu Pratiwi \\ Program Studi Ilmu Pemerintahan, Fakultas Ilmu Sosial dan Ilmu Politik \\ Universitas Riau Kepulauan, Batam, Indonesia \\ diah_mahdan@yahoo.co.id
}

\begin{abstract}
Abstrak
Penelitian ini mengkaji sistem pemilu proporsional terbuka di Indonesia yang melahirkan perilaku korupsi. Tujuan penelitian ini adalah menganalisa sistem pemilu proporsional terbuka yang melahirkan korupsi dikalangan anggota DPR dan DPRD. Penelitian ini menggunakan penelitian kualitatif dengan pendekatan dekriptif. Sumber data yang digunakan, yaitu data primer yang berdasarkan peraturan perundangan dan dokumen resmi yang terkait sistem pemilu di Indonesia. Sedangkan data sekunder meliputi literatur yang relevan dengan penelitian berupa buku, artikel dari majalah, surat kabar, atau jurnal ilmiah, siaran pers, serta penelitian yang terdahulu yang berkaitan dengan sistem pemilu daftar terbuka dan korupsi politik. Temuan penelitian ini menunjukkan bahwa penerapan sistem pemilu proporsional terbuka bertujuan agar menghasilkan wakil rakyat yang akuntabel dan dekat dengan konstituennya. Sistem pemilu ini berpotensi melahirkan korupsi politik karena biaya politik yang mahal selama berkompetisi dalam pemilu.

Kata Kunci: sistem pemilihan umum, proporsional daftar terbuka, legislatif, korupsi politik.
\end{abstract}

\begin{abstract}
This study examines an open proportional electoral system in Indonesia that cause political corrupt. The purpose of this study is to analyze an open proportional election system that generates corruption among members of Parliament and DPRD. This research uses qualitative research with descriptive approach. Sources of data used, namely the primary data based on laws and official documents related to the electoral system in Indonesia. Secondary data include literature that is relevant to research in the form of books, articles magazines, newspapers, or scientific journals, press releases, and previous research relating to open list election systems and political corruption. The findings of this study indicate that the application of an open proportional electoral system aims to produce representative who is accountable and close to the constituents. This electoral system has the potential to generate political corruption due to the expensive political costs of competing in the election.
\end{abstract}

Keywords: open proportional election system, parliaments, political corruption 


\section{PENDAHULUAN}

Penyelenggaraan Pemilhan Umum (Pemilu) merupakan wujud dari sistem demokrasi yang dianut oleh Negara yang demokratis. Pemilu tidak hanya berkaitan dengan kebutuhan pemerintahan akan keabsahan kekuasaannya, tetapi juga sebagai sarana bagi rakyat agar dapat mengartikulasikan aspirasi dan kepentingan dalam kehidupan bersama. Masyarakat dapat memilih wakil-wakil mereka yang akan duduk di parlemen sebagai anggota legislatif atau pemimpin eksekutif melalui pemilu. Pemilu yang diselenggarakan secara transparan dan damai, serta menghasilkan pemimpin yang terpilih oleh suara mayoritas, maka negara tersebut dapat dikatakan sebagai Negara yang demokrasi. Namun sebaliknya, apabila pemilu yang diadakan membawa Negara dalam kekacauan baik vertikal maupu horizontal, maka Negara tersebut dapat dikatan Negara yang gagal dalam melaksanakan demokrasi.

Sistem pemilu merupakan wujud dari demokrasi perwakilan (representative democracy), secara sederhana diartikan sebagai penyaluran kedaulatan rakyat. Asshidique (2011) menjelaskan bahwa ada empat tujuan dari penyelenggaraan pemilu, yakni (1) untuk memungkinkan terjadinya pemilihan kepemimpinan pemerintah secara tertib dan damai; (2) untuk memungkinkan terjadinya pergantian pejabat yang akan mewakili kepentingan rakyat di lembaga perwakilan; (3) untuk melaksanakan prinsip kedaulatan rakyat; (4) untuk melaksanakan prinsip hak-hak asasi warga negara.

Secara umum, ada tiga sistem pemilu di dunia yaitu sistem pluralitas/mayoritas, sistem proporsional, dan sistem campuran (Reynolds, 2005). Keempat rumpun ini melahirkan sedikitnya 12 sistem utama, dimana setiap sistem pemilu memiliki varian masing-masing dan ditetapkan secara berbeda di berbagai Negara di dunia. Lahirnya berbagai macam varian dalam sistem pemilu yang diterapkan oleh berbagai Negara di dunia mempunyai satu tujuan utama, yaitu menutupi kelemahan dari sebuah sistem pemilu namun tetap mempertahankan kelebihannya.

Indonesia merupakan salah satu Negara yang menganut sistem demokrasi dalam menjalankan pemerintahannya. Dalam sejarah perkembangan penyelenggaraan pemilu di Indonesia, sejak tahun 1955 Indonesia menerapkan sistem pemilu representasi proporsional (perwakilan berimbang) dan sistem multipartai sebagai sistem kepartaiannya. Hasil pemilu 1955 menunjukkan bahwa sistem multi partai yang berlaku pada saat itu menghasilkan empat kekuatan utama, yaitu PNI, Masyumi, NU dan PKI dari 170 partai politik (parpol) yang ikut 
dalam pemilu. Pada masa Orde Baru, pemilu dimulai tahun 1971 diikuti oleh 10 kontestan (PNI, NU, Parmusi, Parkindo, Murba, PSII, Perti, Katolik, IPKI, dan Golkar). Pada tahun 19971 diawali perdebatan mengenai kemungkinan perpindahan ke sistem yang memungkinkan para anggota parlemen dapat dipilih secara langsung dengan menggunakan sistem pluralitas/mayoritas (sistem distrik). Namun, pada Pemilu Tahun 1977, 1982, 1987, 1992, dan 1997 sistem yang diterapkan tetap menggunakan sistem representasi proporsional dengan daftar calon tertutup.

Pada masa Orde Baru, Golkar selalu menang mutlak dalam setiap Pemilu dan memiliki kursi mayoritas di Dewan Perwakilan Rakyat (DPR), sehingga selalu mendukung kebijakan rezim Soeharto tanpa adanya kritikan. Dikarenakan selama Orde Baru sistem pemilu tidak dirancang untuk mewadahi berbagai kemungkinan perubahan, maka pada tahun 1998 terjadi gerakan rakyat yang bertujuan untuk merubah situasi dan kondisi yang ada terutama pada politik dan pemerintahan Indonesia. Gerakan ini disebut sebagai gerakan reformasi. Pasca dilengserkannya Soeharto, pada tahun 1999 diselenggarakan pemilu yang diikuti oleh 48 parpol. Pada pemilu tahun 1999 menghasilkan Partai Demokrasi Indonesia Perjuangan (PDIP) sebagai pemenang pemilu, dan partai Golkar diurutan kedua.

Era reformasi merupakan sebuah awal transisi demokrasi dari rezim otoriter menuju rezim yang demokratis. Setelah pemilu 1999, agenda utama yang dilaksanakan adalah melakukan reformasi di bidang politik yang diawali dengan amandemen UUD 1945 oleh MPR yang membahas mengenai sistem pemilu yang diatur secara umum dalam Bab VIIB. Mengacu pada Bab VIIB ini, pilihan sistem pemilu yang akan digunakan sepenuhnya menjadi kewenangan pembentuk undang-undang, yaitu DPR sebagaimana yang diatur dalam Pasal 20 ayat 1 UUD 1945. Amandemen UUD 1945 dilanjutkan dengan perubahan terhadap paket UU bidang politik yang meliputi UU tentang Partai Politik, UU tentang Pemilu, dan UU tentang Susunan dan Kedudukan MPR, DPR, dan DPRD. Sehingga, pada Pasal 22E ayat (2) menyebutkan bahwa pemilihan presiden dan wakil presiden serta pemilihan umum anggota Dewan Perwakilan Daerah (DPD) merupakan bagian dari rezim pemilu, selain pemilu untuk memilih anggota DPR dan DPRD.

Perdebatan mengenai perbaikan sistem pemilu terus menerus bermunculan, setidaknya hingga masuknya Rancangan Undang-Undang (RUU) tentang Pemilu anggota 
DPR, DPD, dan DPRD tahun 2003. Wacana mengenai perubahan sistem pemilu representasi proporsional dengan daftar calon tertutup diganti menjadi sistem distrik (pluralitas/mayoritas) mewarnai perdebatan pada RUU pemilu. Sistem pemilu proporsional yang dilaksanakan pada tahun 1999 sangat jauh dari harapan akan hadirnya akuntabilitas wakil rakyat terhadap konstituen, dikarenakan rakyat tidak mengetahui siapa yang dipilih dan siapa yang terpilih, mengingat pada pemilu 1999 rakyat hanya memilih gambar parpol tanpa mengetahui siapa calonnya. Solusi dari sistem pemilu yang tepat diterapkan di Indonesia adalah sistem distrik, karena memiliki akuntabilitas yang tinggi dibandingkan dengan sistem proporsional. Sistem distrik ini, rakyat mempunyai peranan besar menentukan siapa yang menjadi wakilnya

Terkait RUU pemilu, fraksi-fraksi yang ada di DPR memiliki beragam pandangan mengenai sistem pemilu. Lima parpol besar diantaranya PDIP, Golkar, PKB, PAN, dan PPP memiliki pandangan yang sama bahwa sistem pemilu representasi proporsional masih relevan diterapkan di Indonesia, namun perlu ada perbaikan dalam sistem pengkaderan/ rekrutmen di partai politik. Kemudian lahirlah UU No 12 Tahun 2003 tentang Pemilihan Umum Anggota DPR, DPRD, dan DPD sebagai landasan yuridis penyelenggaraan pemilu tahun 2004. UU pemilu ini menjelaskan bahwa sistem pemilu untuk pemilihan anggota DPR dan DPRD menggunakan sistem proposional daftar terbuka. Sementara, pemilihan anggota DPD menggunakan sistem distrik berwakil banyak. Pemilu 2004 diikuti oleh 24 parpol, dengan partai Golkar sebagai pemenang pemilu dan PDIP menempati diurutan kedua.

Pasca Pemilu 2004, terjadi perdebatan mengenai sistem pemilu ini. Perbedaan pandangan mengenai sistem pemilu terjadi diantara kalangan parpol dan NGO (Organisasi Non Pemerintah). Beberapa parpol, diantaranya PKB dan PDIP merasa dirugikan dengan formula pemilihan atau cara menghitung perolehan kursi dengan menggunakan metode kuota largest remainder atau sisa suara terbanyak. Dimana parpol yang memiliki suara signifikan dalam suatu daerah pemilihan menjadi tidak bermakna ketika dikonversi menjadi kursi akibat dikategorikan sebagai sisa suara yang kalah dibandingkan dengan perolehan suara parpol lainnya yang belum diperhitungkan dalam penghitungan tahap sebelumnya.

Sementara itu, Bagi kalangan NGO seperti CETRO (Centre for Electoral Reform) dan Perludem (Perkumpulan untuk Pemilu dan Demokrasi), sistem pemilu tahun 2004 belum 
mencerminkan sistem yang akuntabel, karena para wakil rakyat masih sangat ditentukan oleh parpol (Pahlevi, 2015). Hal ini mengacu pada Pasal 6 ayat 1 UU No. 12 tahun 2003, yang menjelaskan bahwa calon yang memperoleh suara terbanyak dapat menjadi calon terpilih, akan tetapi ketentuan tersebut dibatasi dengan adanya persyaratan lain yang memberikan ruang bagi parpol dalam menentukan calon terpilihnya, kecuali calon anggota legislatif yang memperoleh suara sesuai Bilangan Pembagi Pemilihan (BPP).

Dalam penyelenggaraan pemilu 2009, tidak berbeda jauh dengan pemilu 2004 yaitu masih menggunakan sistem proporsional dengan daftar terbuka dan penentuan calon terpilihnya melalui suara terbanyak. Perbedaan penyelenggaraan pemilu 2004 dengan 2009 adalah diterapkannya ambang batas parlemen (parliamentary threshold) sebesar 2,5 persen. Peserta pemilu 2009 diikuti oleh 34 parpol nasional dan 6 parpol lokal di Aceh. Parpol yang menempati urutan teratas dalam perolehan suara dan kursi terbanyak ditempati oleh Partai Demokrat, dengan 20,85\% perolehan suara dan 148 perolehan kursi. Partai Golkar menempati urutan kedua dengan perolehan suara $14.45 \%$ dan 106 perolehan kursi (Pengumuman KPU 2009).

Penyelenggaraan Pemilihan Legislatif tahun 2014 dilaksanakan dengan format yang hampir sama dengan pemilu tahun 2009, yaitu menggunakan sistem proporsional daftar terbuka dengan suara terbanyak. Namun, pemilu tahun 2014 menerapkan ambang batas parlemen meningkat menjadi 3,5\%. Sistem pemilu pada tahun 2014 ini mengedepankan keterbukaan, yaitu masyarakat bisa memilih sendiri calon legislatif (caleg) yang mereka dukung. Undang-Undang (UU) yang digunakan untuk pemilu tahun 2014 adalah UU No. 8 Tahun 2012 tentang Pemilihan Umum Anggota Dewan Perwakilan Rakyat, Dewan Perwakilan Daerah dan Dewan Perwakilan Rakyat Daerah

Sistem ini membuat para wakil rakyat semakin dekat dengan konstituennya, sehingga akuntabilitas dalam pelaksanaan fungsi terhadap rakyat semakin nyata. Namun sistem ini juga memiliki kelebihan dan kekurangan. Kelebihan dari sistem proporsional daftar terbuka adalah membuat masyarakat lebih selektif dalam memilih calonnya dan menyeleksi caleg secara rasional. Sementara itu, kelemahan sistem proporsional daftar terbuka adalah suara terbanyak memberikan potensi para caleg menggunakan kekayaannya untuk melakukan pendekatan-pendekatan secara finasial demi memperoleh suara dan dukungan dari 
masyarakat. Jika dipandang dari sisi keadilan, keterwakilan dengan suara terbanyak sangatlah adil, namun dengan suara terbanyak pula dapat timbul perilaku caleg yang mengandalkan modal untuk mempengaruhi massa. Sehingga, muncul pendukung-pendukung yang mudah dimobilisasi demi kepentingan caleg. Pendekatan finansial dapat melahirkan perilaku konstituen (pemilih) yang tidak sehat di tengah-tengah masyarakat.

Selain itu, pola pencalonan legislatif didasarkan pada daftar nama calon dengan nomor urut yang ditentukan oleh partai politik tetapi penetapan calon terpilih dilakukan berdasarkan pada suara terbanyak. Dalam artian bahwa suara yang diberikan oleh pemilih kepada nama calon lebih tinggi nilainya dibandingkan dengan suara yang diberikan oleh pemilih kepada partai politik. Pemilih yang mencoblos berdasarkan pada tanda gambar partai politik hanya ikut mempengaruhi partai politik memperoleh kursi, tetapi tidak ikut menentukan siapa yang menjadi calon terpilih. Hal ini tentu saja akan memperlemah peran partai politik dalam pemilu, dimana parpol hanya sekedar menjadi alat dan kendaraan politik bagi calon legislatif dan konstituen dalam melakukan transaksi jual beli suara. Ketika pemberian suara lebih penting daripada suara parpol, dan ketika penetapan calon terpilih dilakukan berdasarkan jumlah suara terbanyak yang diperoleh calon, maka parpol tidak saja kehilangan legitimasi dari rakyat tetapi juga kehilangan peran sebagai peserta pemilu.

Secara normatif, penyelenggaraan sistem pemilu proporsional daftar terbuka dimaksudkan untuk menghasilkan para wakil rakyat yang akuntabel dan amanah terhadap yang diwakili atau rakyat (konstituen), karena mereka dipilih secara langsung oleh konstituennya. Namun dalam realitasnya, pelaksanaan sistem pemilu proporsional daftar terbuka justru melahirkan sistem pemilu yang berpusat pada calon kandidat, dimana yang terjadi bukan kompetisi antarparpol, melainkan kompetisi antar- calon dari partai yang sama di dapil yang sama (intra-party competition). Karena kompetisi sangat ketat, terjadilah ketidakpastian akan prospek keterpilihan. Makin tidak pasti akan keterpilihan, makin besar kecenderungan melakukan korupsi (mendapatkan uang dari negara secara tidak sah) untuk melakukan kampanye dengan segala cara, termasuk "membeli" suara pemilih (Surbakti, 2016).

Realitas demikian mengakibatkan sistem pemilu proporsional terbuka menjadi sistem pemilu yang sangat mahal dalam sejarah pemilu di Indonesia, terutama bagi para calon 
kandidat karena biaya politik yang tinggi. Mahalnya biaya politik untuk meraih kursi di DPR dan DPRD telah melahirkan perilaku korupsi dikalangan para politisi, terutama mereka yang telah terpilih dan duduk di DPR dan DPRD. Setelah pasca pemilu, korupsi politik yang dilakukan oleh politisi menguat salah satunya karena biaya politik yang dikeluarkan pada saat pemilu tidak sebanding dengan pendapatan yang mereka selama mereka menjabat menjadi politisi.

Berdasarkan realitas tersebut, maka tujuan dari penelitian ini adalah menjawab persoalan mengapa sistem pemilu proporsional daftar terbuka melahirkan korupsi politik dikalangan para politisi.

\section{KERANGKA TEORI}

\section{Sistem Pemilu Proporsional Daftar Terbuka}

Pilihan atas sistem pemilu merupakan salah satu keputusan kelembagaan paling penting bagi demokrasi manapun. Setiap demokrasi harus memilih sebuah sistem pemilu untuk memilih badan legislatifnya. Sementara itu, krisis politik di setiap negara demokrasi membawa momentum bagi perubahan sistem pemilu, bahkan tanpa krisis politik pun para penganjur pembaharuan politik berupaya menjadikanperubahan sistem pemilu sebagai agenda politik.

Keputusan untuk mengubah, atau mempertahankan sebuah sistem pemilu seringkali dipengaruhi oleh dua keadaan, yaitu (1) para aktor politik tidak memiliki pengetahuan dasar dan informasi sehingga berbagai pilihan dan konsekuensi sistem-sistem pemilu yang berlaian tidak sepenuhnya dimengerti; atau (2) para aktor politik menggunakan pengetahuan mereka tentang sistem pemilu untuk mempromosikan desain-desain yang menurut mereka akan menguntungkan bagi keunggulan partisan mereka sendiri (Reynolds, 2005). Pilihan-pilihan tersebut tentu saja memiliki konsekuensi bagi tumbuhnya kesehatan politik yang baik atau justru bisa mendatangkan konsekuensi rusaknya prospek demokrasi di negara tesrsebut.

Sistem pemilu di Indonesia menggunakan sistem proporsional, dimana satu daerah pemilihan memilih beberapa wakil dari partai politik yang ikut dalam pemilu. Sistem pemilu proporsional mengakomodir suara konstituen, sehingga hasilnya lebih representatif. Sistem ini juga mengakui dan menghargai hak-hak politik kaum minoritas dan memberikan ruang publik untuk persaingan antar partai politik. 
Sistem proporsional (proportionate representative) diartikan sebagai sistem transfer suara ke kursi parlemen sesuai dengan proporsi perolehan suara rakyat. Proporsional representatif terdiri dari dua macam, yaitu list yaitu berdasarkan daftar; dan single transferable votes yaitu berdasarkan peringkat. Umumnya Sistem Proporsional Daftar terbuka mempunyai lebih dari satu calon dalam satu daerah pemilihan. Hal ini menunjukkan bahwa akan ada lebih dari satu kursi parlemen yang akan diperebutkan. Di Indonesia, jumlah minimal kursi dalam satu daerah pemilihan adalah tiga kursi. List memiliki tiga pola, yaitu daftar tertutup atau close list, daftar terbuka atau open list dan daftar bebas atau free list (Reynolds, 2005). Pada sistem daftar terbuka, pemilih tidak hanya dapat memilih partai pilihan mereka, namun juga kandidat yang diusung dalam partai tersebut.

Pada pola daftar terbuka, calon adalah yang utama atau candidate centered. Hal ini membuat calon dari partai yang sama harus bersaing untuk mendapatkan suara. Tentunya hal ini berpotensi untuk melahirkan konflik internal partai dan juga keadaan antar calon yang fragmentasi. Kondisi tersebut membuat para calon harus menjaring suara konstituennya dengan memaksimalkan pendekatan secara personal dan mengurangi penggunaan nama partai saat melakukan pendekatan. Bagi para calon yang memiliki hubungan dan jaringan sosial yang baik dan kepemimpinan yang kuat di masyarakat, maka hanya perlu mempererat loyalitas dari para konstituennya untuk dapat menang.

Sistem Proporsional Daftar Terbuka juga merupakan sistem pemilihan umum dimana kursi yang tersedia di parlemen pusat akan diperebutkan oleh partai politik yang ikut serta dalam pemilihan umum sesuai dengan perimbangan suara yang diperoleh partai politik tersebut. Perimbangan dapat digambarkan seperti ini, 1:400.000 yang berarti 400.000 pemilih diwakili oleh satu wakil di parlemen. Negara dilihat sebagai suatu daerah pemilihan dimana suara yang diperoleh seorang calon di suatu daerah dapat ditambahkan dengan perolehan suara dari daerah lain, sehingga besar kemungkinan setiap partai politik akan memperoleh kursi di parlemen pusat.

Sistem Proporsional Daftar Terbuka merupakan sistem yang diusulkan oleh pemerintah dan dituangkan dalam Undang-Undang Pemilu Nomor 8 Tahun 2012. Dalam sistem ini, rakyat langsung memilih calon yang diusulkan oleh partai politik. Sistem ini meningkatkan akuntabilitas wakil rakyat terhadap konstituennya. Secara konkret, wakil rakyat di suatu daerah pemilihan akan diketahui jelas oleh rakyat di daerah tersebut. Rakyat mengetahui siapa yang mewakili mereka dan siapa yang bertanggungjawab untuk 
menyuarakan suara mereka di parlemen.

\section{Korupsi Politik}

Korupsi politik secara sederhana dapat diartikan sebagai tindakan melawan hukum dan moral karena menyalahgunakan kekuasaan dan kewenanagan yang dimiliki seseorang untuk kepentingan dirinya, kelompok atau pihak-pihak lain yang untuk saling mencari keuntungan secara ekonomi maupun politik (Alkostar, 2010). Pejabat negara yang terlibat dalam korupsi politik biasanya menggunakan kewenangan yang ada ditangannya untuk mendapatkan keuntungan, baik material maupun non material.

Definisi korupsi politik sendiri menurut Kamus Internasional Hukum dan Legal adalah penyalahgunaan kekuasaaan politik oleh pemimpin pemerintahan untuk mendapatkan keuntungan pribadi dan korupsi politik juga berarti melakukan tindakan korupsi untuk mempertahankan kekuasaan. Namun, penggunaan kekuasaan untuk tujuan lain misalnya represi terhadap lawan politik dan penggunaan polisi secara brutal tidak termasuk korupsi politik. Korupsi politik terjadi pada tingkat tertinggi dalam suatu sistem politik, dan dapat dibedakan dari administrasi dan korupsi birokrasi. Dia juga dapat dibedakan dari bisnis dan korupsi sektor privat (Purbolaksono, 2017).

Korupsi politik dapat terjadi dalam dua bentuk. Pertama, akumulasi dan ekstraksi di mana pejabat pemerintah menggunakan dan menyalahgunakan kekuasaan yang ada ditangannya untuk mendapatkan keuntungan dari sektor privat, dari pajak pemerintah, dan dari sumber ekonomi secara besar-besaran. Contohnya adalah korupsi yang dilakukan sebagai rent-seeking di mana para calon pemimpin mencari modal keterpilihannya melalui janji pemberian proyek tertentu kepada pemodal politiknya ketika dia menjabat. Kedua adalah mengambil keuntungan dari sumber-sumber seperti dana publik untuk menyelamatkan dan memperkuat kekuasaannya. Hal ini biasanya dilakukan dengan memberikan dukungan dan patronasi politik kepada kelompok tertentu. Termasuk didalamnya adalah distribusi keuangan dan material yang memberikan manfaat, keuntungan dan memanjakan pihak tertentu (Purbolaksono, 2017)

\section{METODE PENELITIAN}

Penelitian ini akan menggunakan pendekatan kualitatif yaitu pendekatan yang menekankan pada penarikan kesimpulan berdasarkan interpretasi terhadap suatu fenomena 
ataupun fakta. Proses penelitian kualitatif lazimnya mengikuti pola induktif dimana penelitian diawali dengan pengamatan terhadap suatu fenomena atau fakta empiris yang spesifik dan unik yang kemudian diterjemahkan menjadi sebuah generalisasi empiris yang pada akhirnya dapat menghasilkan sebuah teori baru mengenai fenomena atau fakta yang diteliti. Adapun metode penelitian yang digunakan adalah metode studi kasus (case study); berdasarkan pemikiran Bryman (2004) bahwa studi kasus merupakan suatu analisis yang seksama dan intensif terhadap sebuah kasus tunggal. Metode ini biasanya mencoba untuk memahami kompleksitas dan sifat khas dari kasus yang diteliti; fokus penelitian antara lain terhadap suatu komunitas, sekolah, keluarga, organisasi, individu, atau peristiwa tertentu.

Dalam konteks penelitian ini akan mengikuti pemikiran Bennet (2004) mengenai definisi studi kasus yaitu analisa mengenai suatu aspek dari peristiwa sejarah yang didefinisikan secara baik. Bennet juga menambahkan mengenai suatu peristiwa sejarah yang terdiri dari bermacam-macam variabel, diantaranya variabel bebas (independent) dan variabel terikat (dependent), sehingga dalam suatu studi kasus seorang peneliti dapat memfokuskan diri terhadap aspek-aspek yang menarik baginya.

Penelitian ini memusatkan pada penelitian atas bahan-bahan berupa peraturan perundangan, maupun dokumen resmi yang terkait sistem pemilu di Indonesia. Penelitian ini disajikan dalam bentuk deskriptif analisis. Pengumpulan data sekunder meliputi literatur yang relevan dengan penelitian berupa buku, artikel dari majalah, surat kabar, atau jurnal ilmiah, kliping, siaran pers, serta penelitian yang terdahulu yang berkaitan dengan sistem pemilu daftar terbuka dan korupsi politik.

\section{PEMBAHASAN}

\section{Pro-Kontra Sistem Pemilu Proporsional Daftar Terbuka}

Sistem pemilu di Indonesia telah mengalami perubahan, dari sistem proporsional daftar tertutup menjadi daftar tebuka. Dalam perubahan tersebut tidak sepenuhnya terbuka, namun lebih cenderung pada sistem proporsional semi daftar terbuka. Hal ini dikarenakan dalam penentuan mengenai siapa yang akan mewakili partai dalam perolehan kursi di parlemen tidak didasarkan pada perolehan suara terbanyak melainkan tetap berdasarkan pada nomor urut. Meskipun ada calon kandidat diluar nomor urut, maka calon tersebut harus memiliki suara yang mencukupi Bilangan Pembagi Pemilih (BPP) (Marijan, 2012). 
Keputusan MK Nomor 22 dan 24/PUU-VI/2008 yang mengabulkan permohonan pengujian undang-undang Pasal 124 Undang-Undang Nomor 10 Tahun 2008 tentang Pemilihan Umum Anggota DPR, DPRD, dan DPD. Putusan inilah yang mengubah sistem pemilu di Indonesia menjadi sistem pemilu proporsional daftar terbuka dengan suara terbanyak. Permasalahan pun muncul dalam keputusan tersebut, karena MK tidak merinci mengenai apakah suara terbanyak diartikan sebagai mayoritas atau pluralitas. Mengingat sistem pemilu mengalami perubahan, namun terdapat usulan untuk melakukan modifikasi sistem proporsional lanjutan. Apabila pada pemilu 2004 menggunakan sistem daftar setengah terbuka, untuk pemilu selanjutnya terdapat usualan untuk menggunakan sistem daftar terbuka. Dengan demikian, nomor urut daftar calon tidak lagi menjadi ukuran untuk menentukan calon mana yang mewakili partai di dalam perolehan kursi. Suara terbanyak menjadi ukuran dalam menentukan calon yang terpilih.

Penerapan sistem pemilu proporsional daftar terbuka tdak terlepas dari pro dan kontra di kalangan masyarakat, tetapi juga dikalangan fraksi yang duduk di parlemen dalam merumuskan RUU tentang Pemilu Anggota DPR, DPD, dan DPRD. Perdebatan yang lebih substantif tentang sistem pemilu terjadi pada tahun 2008 ketika dilakukan proses perumusan terhadap RUU tentang Pemilu Anggota DPR, DPD, dan DPRD yang kemudian menjadi UU Nomor 10 Tahun 2008. Pembahasan mengenai pilihan sistem pemilu menjadi materi utama yang diperdebatkan, yaitu apakah hendak menggunakan sistem proporsional terbuka, atau proporsional terbuka terbatas, atau kembali menggunakan sistem proporsional tertutup. Pembahasan lainnya yang memiliki kaitan langsung dengan pilihan sistem pemilu adalah beberapa aspek lain dalam sistem pemilu, yaitu pembentukan daerah pemilihan, alokasi kursi tiap daerah pemilihan, ambang batas (threshold), dan konversi suara menjadi kursi. Aspekaspek tersebut menjadi bagian dari proses perumusan terhadap sistem pemilu secara keseluruhan.

Pada akhirnya Undang-Undang Nomor 10 tahun 2008 tentang Pemilu Anggota DPR, DPD, dan DPRD direvisi menjadi Undang-Undnag Nomor 8 Tahun 2012 dengan menetapkan sistem pemilu tahun 2014 menggunakan sistem pemilu proporsional daftar terbuka. Apabila dicermati, saat ini sudah digunakan sistem suara terbanyak dalam penentuan calon terpilih, melalui formula pemilihan yang diatur dalam UU. Terdapat kecenderungan penggunaan sistem pluralitas-mayoritas (plurality-majority) meskipun dengan dasar sistem perwakilan berimbang (proportional representation). Namun demikian tujuan utama dari 
proses perumusan sistem pemilu ini adalah mendekatkan antara wakil dan yang diwakili (rakyat atau konstituen).

Namun, sistem pemilu proporsional terbuka ini terus disorot karena dinilai sebagai tingginya biaya politik, khususnya bagi calon kandidat. Biaya kampanye masing-masing calon anggota legiilatif dalam setiap penyelenggaraan pemilu akan mengalami kenaikan terus menerus. Hal ini dapat dilihat dari penyelenggaraan pemilu 2009, biaya kampanye diperkirakan mencapai 3,3 milyar rupiah dan pada tahun 2014 biaya kampanye mengalami kenaikan yang cukup tinggi diperkirakan dapat mencapai 4,6 milyar rupiah.

\section{Sistem Pemilu Proporsional Daftar Terbuka Dan Korupsi Politik}

Sistem pemilu proporsional daftar terbuka dengan suara terbanyak tidak hanya memperlemah partai politik sebagai sebuah institusi demokrasi menjadi sekedar event organizer tetapi juga dapat memberikan insentif bagi para calon legislatif, pemilih dan petugas pemilu dalam transaksi jual beli suara. Ketika suara yang diberikan kepada nama calon lebih penting daripada suara yang diberikan kepada Partai Politik, dan ketika penetapan calon terpilih dilakukan berdasarkan urutan jumlah suara yang diperoleh calon, maka Partai Politik tidak saja kehilangan legitimasi dari rakyat tetapi juga kehilangan peran sebagai peserta pemilu. Ketika jumlah kursi yang diperebutkan di setiap Dapil berkisar antara 4 sampai dengan 9 kursi, maka peluang partai politik 'kecil' memperoleh kursi semakin besar. Seorang calon tidak perlu mencapai suara mayoritas ataupun BPP untuk dapat ditetapkan sebagai calon terpilih. Seorang calon hanya memerlukan jumlah suara lebih banyak daripada jumlah suara calon lain dari Partai yang sama dan di Dapil yang sama untuk ditetapkan sebagai calon terpilih. Ketika peran calon jauh lebih penting daripada partai dalam melakukan kampanye, maka Besaran Dapil ukuran Sedang dan penetapan calon terpilih berdasarkan jumlah suara lebih banyak merupakan potensi untuk melakukan transaksi jual beli suara. Jual beli suara akan difasilitasi oleh Partai Politik pemegang otoritas apakah calon tersebut nantinya akan diberi suara atau tidak. Hal ini menyebabkan setelah calon terpilih duduk di parlemen, mereka berlomba-lomba mencari modal guna mengembalikan mahar.

Selain itu, sistem ini akan meminimalkan loyalitas calon terhadap parpol. Hal ini terlihat dari banyaknya politikus yang pindah partai karena partai asalnya tidak mengusung dalam pemilu legislatif. Tentu saja ini akan melahirkan calon legislatif karbitan dan mengakibatkan krisis kewibawaan parpol. Sistem pemilu ini juga menstimulasi kampanye 
berpusat pada calon. Reputasi personal calon lebih penting daripada reputasi partai. Tidak heran apabila sistem pemilu seperti ini seringkali disebut sebagai Sistem Pemilu Proporsional yang berpusat pada kandidat. Hal ini tidak lain karena setiap calon melakukan kampanye relatif bebas dari intervensi partai politik yang mencalonkan. Calon tidak hanya menentukan strategi dan taktik kampanye, tetapi juga menentukan tema kampanye. Calon tidak hanya mencari dana kampanye sendiri, tetapi juga menentukan sendiri penggunaan dananya (Surbakti, 2016). Perolehan suara terbanyak dalam pemilu belum tentu identik dengan kualitas politisi yang duduk di parlemen, karena sistem pemilu ini membuka peluang bagi calon-calon popular untuk dipilih tanpa kompetensi, dibandingkan dengan calon-calon berkompeten tapi tidak popular. Dari sisi sirkulasi elite sistem suara terbanyak memang sangat baik, namun dari sisi kualitas belum menjamin kualitas yang duduk di lembaga parlemen.

Dalam penentuan calon terpilih, Mietzner (2009) menjelaskan bahwa sistem penentuan calon terpilih berdasarkan suara terbanyak telah menjadikan pemilu menjadi sangat mahal dan melahirkan problem yang multikompleks. Pengaturan sistem pemilu 2009 dan 2014 yang didasarkan pada suara terbanyak telah memprovokasi lahirnya model kompetisi antar calon dalam pemilu yang tidak sehat. Sebab, orientasi meraih suara terbanyak telah mendorong caleg banyak melakukan kecurangan guna merayu pemilih dalam berbagai bentuk, seperti: pembagian uang tunai antara Rp. 50.000 - Rp.200.000 per pemilih, pemberian door prize, bantuan sosial, pembelian pulsa, pemberian pakaian, pengobatan gratis hingga perbaikan infrastruktur seperti pengaspalan jalan, semenisasi dan perbaikan fasilitas publik. Berbagai bentuk kecurangan ini dapat dikualifikasikan sebagai politik uang (Riwanto, 2014).

Berangkat dari realitas diatas, dapat diasumsikan bahwa sistem pemilu proporsional daftar terbuka dengan suara terbanyak merupakan pemilu dengan biaya politik yang tinggi. Hasil riset Lembaga Penyelidikan Ekonomi dan Masyarakat Universutas Indonesia (LPEMFEUI) merilis biaya kampanye caleg DPR mencapai Rp.1,18 miliar - Rp.4,6 miliar. rentang biaya kampanye caleg DPR yakni kurang dari Rp.787 juta (kurang/sedikit), Rp.787 juta Rp1,18 miliar (optimal), Rp1,18 miliar - Rp.4,6 miliar (wajar), Rp.4,6 miliar - Rp.9,3 miliar (tidak wajar) dan lebih dari Rp.9,3 miliar (tidak rasional). Sementara berdasarkan hasil penelitian, biaya kampanye seorang caleg DPRD provinsi yakni kurang dari Rp.320 juta (kurang/ sedikit), Rp.320 - Rp.481 juta (optimal), Rp.481 juta - Rp.1,55 miliar (wajar), 
Rp.1,55 miliar -- Rp3 miliar (tidak wajar), lebih besar dari Rp.3 miliar (tidak rasional). Dana sebesar itu untuk keperluan: percetakan, tekstil, transportasi dan komunikasi, jasa komunikasi media, dan pengerahan massa (Antara Bali News, 2014). Lebih lanjut LPEMFEUI menjelaskan bahwa pendapatan yang diperoleh anggota DPR selama lima tahun yakni Rp.5,3 miliar - Rp.5,4 miliar. Sementara pendapatan seorang anggota DPRD provinsi, yakni Rp.1,6 miliar - Rp1,8 miliar. Rentang pendapatan tersebut berasal dari pendapatan resmi maupun tidak resmi. seorang caleg akan jor-joran dalam membiayai kampanyenya dengan harapan caleg tersebut bisa mengembalikan modalnya ketika dia berhasil menjabat sebagai anggota dewan (Dewi, 2014).

Logikanya, biaya politik yang begitu mahal pada saat kampanye menimbulkan potensi besar bagi anggota DPR dan DPRD yang terpilih berperilaku korupsi politik. Para anggota DPR dan DPRD harus mengembalikan modal uang yang dilakukan saat berkompetisi dalam pemilu. Perilaku korupsi politik ini diperkuat dari tahun ke tahun, selalu saja ada kasus - kasus korupsi yang menjerat anggota DPR oleh Komisi Pemberantasan Korupsi (KPK). Berbagai kasus suap dan korupsi menjerat para anggota DPR dan DPRD. Pada periode 2009 - 2014 sebanyak 36 orang anggota DPR dari berbagai lintas partai terjerat kasus korupsi. Sementara itu, sejak dilantik pada tanggal 1 Oktober 2014, sudah 7 (tujuh) orang dari 560 anggota DPR periode 2014 - 2019 ditangkap oleh KPK dengan dugaan menerima suap.

Motif korupsi yang dilakukan oleh anggota DPR selain untuk mengembalikan modal pada saat kampanye pemilu, juga disebabkan tidak jelasnya model pembiayaan organisasi partai politik untuk survavilitas partai. Sisi investasi finansial untuk memenuhi kebutuhan partai tak terbatas. Pada saat bersamaan, partai adalah institusi yang didesain tidak dengan motif mencari laba. Partai adalah institusi nirlaba, tetapi melibatkan investasi tak terhingga. (Pamungkas, 2008).

Idealnya, sistem pemilu merupakan perwujudan dari kedaulatan rakyat. Namun, melihat realitas yang terjadi saat ini kedaulatan rakyat tergantikan dengan kedaulatan uang. Dimana uang menjadi faktor utama kemenangan parpol dan caleg dalam pemilu, dengan mengabaikan ide, gagasan dan platform partai politik itu sendiri. 


\section{KESIMPULAN}

Hasil penelitian ini menunjukkan bahwa:

1. Penerapan sistem pemilu proporsional daftar terbuka dengan suara terbanyak di Indonesia dimaksudkan agar dapat menghasilkan para wakil rakyat yang akuntabel dan dekat dengan konstituennya.

2. Partai politik perlu memperkuat sistem rekrutmen dan kaderisasi politik guna menghindari rekrutmen instan yang didasarkan pada popularitas, guna menghindari munculnya calon legislatif karbitan.

3. Sistem pemilu proporsional daftar terbuka dngan suara terbanyak ini berpotensi menimbulakn perilaku korupsi politik di kalangan anggota DPR dan DPRD dikarenakan biaya politik selama pemilu yang sangat mahal.

4. Memperkuat penyelenggaraan pemilu dalam pencegahan, pengawasan, dan penindakan praktik politik uang guna mencegah terjadinya korupsi politik.

\section{DAFTAR PUSTAKA}

Asshidique, Jimmly. (2011). Pengantar Ilmu Hukum Tata Negara. Edisi I Cet. Ketiga. Jakarta: Rajawali Pers.

Bennett, Andrew. (2004). Case Study Methods: Design, Use, and Comparative Advantages, Models, Numbers, and Cases: Methods for Studying International Relations, Eds. Detlef F. Sprinz \& Yael Wolinsky-Nahmias, Ann Arbor: University of Michigan Press.

Bryman, Alan. (2004). Social Research Methods. Second edition. New York: Oxford University Press.

Dewi, Anita Permata. (2014). Biaya Kampanye Seorang Caleg DPR Ditaksir Rp. 1,18 Miliar. Antara Bali News. Di unduh dari https://bali.antaranews.com/berita/50027/biaya-kampanye-seorang-caleg-dpr-ditaksirrp118-miliar Januari 2018.

Marijan, Kacung. (2012). Sistem politik Indonesia: Konsolidasi Demokrasi Pasca Orde Baru. Jakarta: Kencana.

Mietzner, Marcus. (2009). Indonesia's 2009 Election: Populism, Dynesties, and The 
Consolidated of the Party System, Analysis, Paper, Sydney: Lowy Institute for International Policy.

Pahlevi, I. (2015). Sistem Pemilu Di Indonesia Antara Proporsional dan Mayoritarian. (I. Pahlevi, Ed.) (Edisi Pert). Jakarta: Pusat Pengkajian, Pengolahan Data dan Informasi (P3DI).

Pamungkas, Sigit. (2008). Korupsi dan Politikus. Kompas, 7 Agustus 2008. di unduh di http://sigitp.staff.ugm.ac.id/?p=10 tanggal Januari 2018.

Purbolaksono, Arifanto. (2017). Korupsi Politik di Kasus E-KTP. Di unduh dari https://theindonesianinstitute.com/korupsi-politik-di-kasus-e-ktp.html Januari 2018.

Riwanto, Agus. (2014). Menyoal Kecurangan Pemilu. Republika. Di unduh dari https://www.google.com/search?safe=strict\&sxsrf=ALeKk01NUraUr5Iz4iLcImXGTcY 4ADhV7g\%3A1582198335399\&ei=P25OXoP8F9Ke4-

EPxvyH0A8\&q=Riwanto\%2C+Agus. $+\% 282014 \% 29 .+$ Menyoal + Kecurangan + Pemilu. + Republika\%2C+30+April+2014\&oq=Riwanto\%2C+Agus.+\%282014\%29.+Menyoal+K ecurangan+Pemilu.+Republika\%2C+30+April+2014\&gs_l=psyab.12...301744.301744..303951..0.0..0.984.1991.0j1j6-2.....0...2j1...gwswiz.......35i39.GDNixKfqz6E\&ved=0ahUKEwjD1_uNhODnAhVSzzgGHUbAfoQ4dUDCAo Januari 2018.

Reynolds, Andrew. Reilly, Ben \& Ellis, Andrew (2005). Desain Sistem Pemilu: Buku Panduan Baru International IDEA. (K. N. Agustyati, Ed.) (Edisi Terj). Swedia: International IDEA.

Surbakti, R. (2016). Korupsi dan Sistem Pemilu. Opini Kompas, pp. 1-4. di unduh di https://www.aipi.or.id/admin/assets/pdf/pdf_file/27052016_Korupsi_dan_Sistem_Pemil u.pdf.

Artidjo, Alkostar. 2010. Korupsi Politik Di Negara Modern. Yogyakarta: FH UII Press. 